\title{
THE ROLE OF CHANGE AGENTS IN COMMUNITY EMPOWERMENT USING INFORMATION AND COMMUNICATION TECHNOLOGY (ICT): CASE STUDY AT DESA KALIABU, CENTRAL JAVA
}

\author{
Mira Azzasyofia \\ Bandung Polytechnic of Social Welfare (Poltekesos), Ir. H. Juanda Street (Dago), No. 367, \\ Bandung, mirazzasyofia@gmail.com \\ Isbandi Rukminto Adi \\ University of Indonesia (UI), Margonda Raya Street, Pondok Cina, Beji, Depok, \\ isru50@ui.ac.id \\ Admiral Nelson Aritonang* \\ Bandung Polytechnic of Social Welfare (Poltekesos), Ir. H. Juanda Street (Dago), No. 367 \\ Bandung, nelsonaritonang@yahoo.com
}

Note: *correspondence

\begin{abstract}
In achieved the development in rural area, there needs to be empowerment of the rural community. The success of rural community empowerment is determined by the existence of a capable change agents to help communities improve their own strength. Desa Kaliabu, Central Java became one of the villages that succeeded in community empowerment by the utilization of Information and Communication Technology (ICT) due to the existence of change agents. Methodically using qualitative research method, this study describes the role of change agents at Desa Kaliabu in community empowerment by the utilization of ICT. This study reveals that change agents in Desa Kaliabu have educational, technical, representational, and facilitative roles and skills. Educational roles are owned consisting of Consciousness-raising, informing, and training. The technical roles consist of the ability to use computers and financial control. Meanwhile the representational roles consist of advocacy, networking, and sharing knowledge and experience. While facilitative roles seen from the existence of personal communication, utilization of skill and resources, social animation, and mediation.
\end{abstract}

\section{Keywords:}

Change agents, Community empowerment, Poverty alleviation, Community development 


\section{INTRODUCTION}

Villagers are vulnerable to poverty and are often left behind in development. In the Indonesian Law No.6 of 2014 on Villages mentioned that the development of the village is an effort to improve the quality of life and life for the greatest welfare of village communities. To realize the development of villages, there is need for empowerment of village communities. According to Ife (2013) empowerment is done to increase the strength of disadvantaged people to make decisions and determine opportunities in life; set their needs; thinking; engaging with institutions; gain access and be able to utilize resources; engaging in economic activity; as well as controlling reproduction through policy and planning, social and political action as well as education. From the sense expressed by Ife, suggests if empowerment is aimed at the disadvantaged people. Villagers are disadvantaged people because they are often unaffected by development. Thus, there needs to be empowerment for the village community to participate in development.

Empowerment according to the World Bank is the expansion of assets and capabilities of the poor to participate, negotiate, influence, control, and hold institutional responsibilities that affect their lives (Narayan, 2002). While Adams (1990, p.43), expresses empowerment as individuals, groups and/or societies that control their circumstances and achieve their own goals, so as to work to maximize their quality of life. The empowerment process operates at the individual, group, family, organization and community level, as well as in various sectors of human life. Therefore, empowerment is not only done individually but can be in groups or in the community. The two key changes from the foundation of empowerment are changes in the way professionals negotiate and use their power and change in the user accessing their power resources (Braye \& PrestonShoot, 1995, p. 188). Therefore, in an effort to empower the existence of change agents that are able to encourage the community to increase the power of society and make changes is needed. The expected role of change agents in the empowerment of rural communities is to use a non-directive approach, where this approach assumes that people know what they really need and what is good for them (Adi, 2013). This approach is right done because in empowerment is about a person able to control his own life and have abilities to determine their own future (Shardlow, 1998).

The emergence of change agents in society is due to the emergence of dissatisfaction in society so that they feel the need to perform an action until they can feel satisfied with the results achieved. Batten (1967) in Adi (2013) reveals this process as a thinking process. Stages of the thinking process can be generated due to various motivations. According to Zander (1990) in Adi (2013), there are four kinds of motivation: self-oriented, desire for group success, willingness to please others, and desire to help society. The existence of change agents in a community is sometimes a factor that influences the success of community empowerment. One way to empower society is using Information Communication and Technology (ICT).

Information and Communication Technology (ICT) can be beneficial to the human quality of life, especially in developing countries (Kivunikea et.all, 2011). The spread of ICT in developing countries implies not 
only the provision of content that is appropriate and meaningful to local communities, but also a good understanding of how ICTs are catalyzing what information and mechanisms that activate that context (Andrade \& Urquhart, 2009). In other words, the proper used of ICT will be able to play an important role in connecting the poor with information, as well as to each other or with the wider society (Narayan, 2002).

In maximizing the utilization of ICT, the opening of ICT access should be accompanied by the ability to use the access to ICT. Without the capabilities and capacity of people to be educated, and to be able to absorb and process complex information then effective utilization of ICT existence will be hampered (Castells, 1999). Thus, the expertise to utilize ICT is essential, this skill can be either basic, advanced, or specialist (OECD, 2005). Meanwhile, Ng (2015) calls this skill on ICT with term digital literacy. Digital literacy as the integrated cognitive technical and social-emotional ability of an individual to competently use digital technologies across the various contexts of people life. Furthermore, Ng (2015) states a digitally competent person is a digitally literate person who is abled to use a combination of the skills and knowledge In Indonesia, the development of the internet is the impact of increased access and ICT infrastructure by the government Based on BPS (2017), the ICT development index of the access and infrastructure subindexes scored 5.46 from the rating scale of 10 , while the skill sub-index scored the highest with a value of 6.81 . While the value of subindex use get of a complete task of digital technology. the lowest value with scored 3.20. The high scored on the skill sub-indexed should be maximized to increase the use of existing ICT access and infrastructure. The low value of the use of ICT in Indonesia is due to the use of internet access in Indonesia more often used by the community as a means of socialization or communication (Puskakom UI, 2015).

\section{Reasons for accessing the internet (from PC/Computer)}

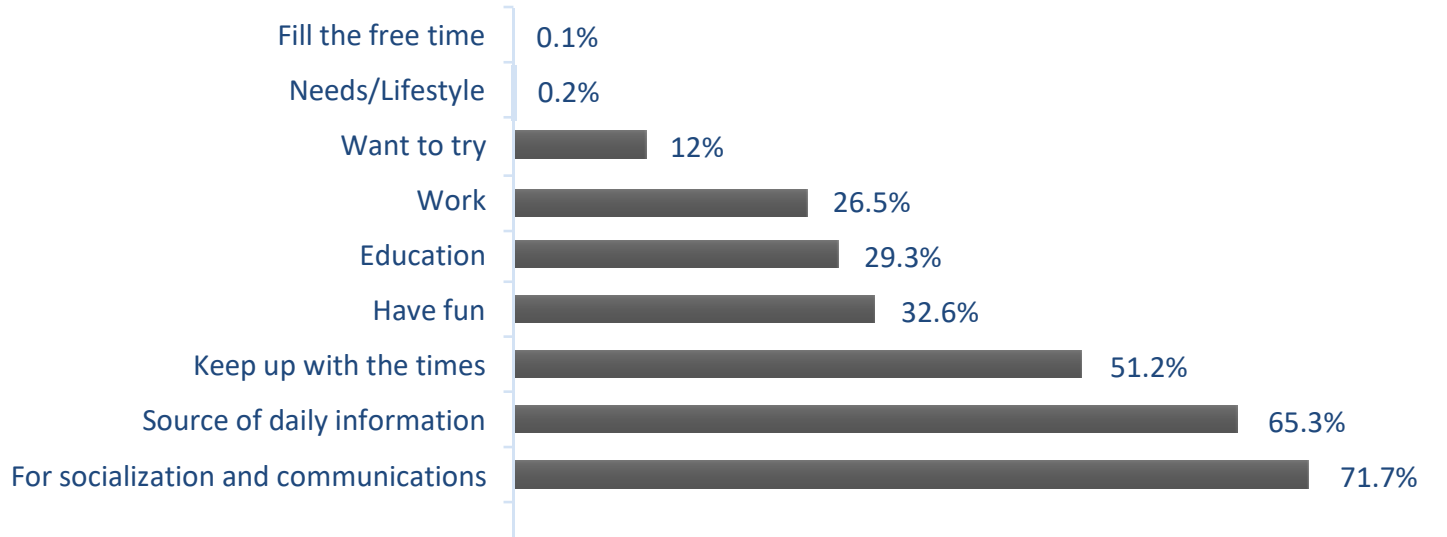

Figure 1 Reasons for accesing the internet (from PC/Computer) in Indonesia Source: Puskakom UI, 2015 
Based on the Puskakom UI (2015) as seen in figure 1 above, the use of internet access has not been used for activities that support the community to be able to support for the improvement of development and empowerment. Ahmad \& Al-Roubaie (2013) says it is necessary to invest in building ICT capacity including educating and training people about the use of ICT in order to use it to use for empowering people and improving living conditions. Meanwhile, Kivunikea, et.all (2011) revealed the adoption of ICT by rural poor is still in its early stages and there is still limited awareness of the potential of ICT on quality of life. To this end, the policy towards ICT is expected to not only focus on

\section{METHOD}

This study aims to provide a description of the role of change agents in empowerment using ICT with collecting data and information to get an overall picture of the role of change agents in Desa Kaliabu. Based on these goals, this research uses a qualitative approach. This study conducted in 2017. In addition, this study describes in depth the conditions that occured in the field based on data, facts and information that focuses on the observation of the use of ICT in Desa Kaliabu. Therefore, this kind of research method used in this research is descriptive study. Descriptive study is a study whose main purpose is to "paint a picture" using words or numbers and to present profiles, classifications, or outline steps to answer questions such as who, when, where, and how (Neuman, 2014).Purposive sampling used asa informant selection technique. Based on this technique selected twentytwo informants, consisting of government officials, community and religious leaders, as well as the availability and affordability, but also consider expanding public awareness for development benefits. One that can be done to raise public awareness of the maximum utilization of ICT so that it can achieve development is by increasing Human Capital. Change agents in a community can use ICT to improve the quality of life in community. Thus, this study will discuss the role of change agents in community empowerment especially empowerment by the utilization of ICT. The goal of this paper is to shows the role of change agents at Desa Kaliabu, Central Java on community empowerment using ICT especially through logo designer job.

community who involved in empowerment using ICT in Desa Kaliabu. Results of interviews obtained directly from the informant is the primary data in this study. Primary data is then given the code and grouped first before then done the analysis. The analysis is done by linking and comparing the relationship between each code so that generalizations can be made or general conclusions from the analysis. In conducting data analysis, this study uses data processing scheme in research disclosed by Ellen (1984) in Neuman (2014), as depicted in Figure 1 below

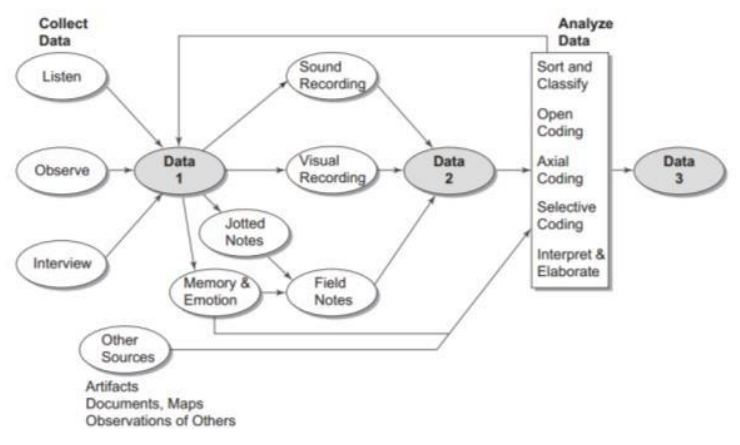

Figure 2 Data in Research

Source: Ellen (1984) in Neuman (2014,p. 488) 


\section{RESULT}

Desa Kaliabu located in Kecamatan Salaman, Kabupaten Magelang, Central Java Province. Since 2010, Desa Kaliabu has become a village known to the public because of the success of empowering by the utilization of Information and Communication Technology (ICT). Communities in Desa Kaliabu, more of whom have educational background at junior high school level. This is due to the lack of education facilities in this village. Meanwhile, the main livelihoods in this village are as farmers or factory workers. However, this does not prevent the entry of ICT access in this village. Desa Kaliabu became a village that almost all of its residents have gained access to ICT. This is because of the introduction to the public against the use of ICT is able to make them get online job with a logo designer profession. The result of this study will separate into to section, the first one is impact of the used of ICT on human capital in rural area and the role of change agents in community empowerment using ICT.

\section{Impact of The Used of ICT on Human Capital in Rural Area}

Despite having minimal educational background, the creativity of Desa Kaliabu community becomes an advantage. They easily accept outside influences and pack them in their own culture. Creativity into excellence and initial asset that must be owned by people, especially those who plunge into logo designers. Other than creativity, mental competition is a musthave before plunging into a logo designer, so of course people who jumped as a logo designer already has a mental competition. Without a mental competition is difficult for people to be able to compete and plunge as a logo designer. This is because the marketplace that is used to find a job package the work offered in the form of competition. Thus, the mental competition to compete and ready to accept defeat must be had. In cultivating and growing mental competition in the community especially those who plunge to become logo designers, followed by the level of motivation they have. Motivation of people who plunge into a diverse logo designer and the motivation is not always a positive motivation. One of the most frequent motivations in a community that plunges into a logo design profession is the desire to emulate what others have in order to force themselves to achieve it. While the other motivation is to prove themselves whether he can be better than others. With minimal educational background and work that is not in line with the logo design profession, people want to prove if they are able to do what is done by others.

\section{a. Impact on Rural Skills}

The use of ICT conducted in Desa Kaliabu is due to the introduction of the opportunity to get online job by becoming a logo designer. Thus, the use of ICT is done not only take advantage of access to the internet, but also by using graphic design software. To that end, the use of ICT has improved the skills of Desa Kaliabu community in the field of ICT. The ability to use computer applications and the ability to find the right information is the main condition that supports to do the job as a logo designer. People's knowledge of this also increases. People who initially only graduated from elementary, junior high school, or high school and do not have the background especially the ability in 
the field of graphic design is now gained that ability.

Increased knowledge of computer use is experienced by $\mathrm{WN}, \mathrm{WN}$ is a 26-yearold youth. He is a graduate of MTS or Junior High School and works in an iron factory in his village. WN never knew how to operate a computer before. However, after being introduced to the logo designer profession, WN became aware of how to operate a computer, especially how to turn on and off the computer device. Not only that, WN now has the expertise to use graphic design software. In addition to $\mathrm{WN}, \mathrm{MJ}$ also experienced the same thing. As an STM or High School graduate, MJ did not really know how to operate the computer but after being introduced with the opportunity to get an online job, MJ was interested to learn and improve his expertise in the field of ICT. First time using the computer, MJ was originally introduced by his friend. However, after the introduction, MJ chose to self-taught study. MJ improves his skills in using graphic design software by looking at the guides and tutorials on Youtube or blogs through searching information form google. Thus, not only his ability to operate a computer and use graphic design alone increases but the ability to search for information that he need increases. MJ and other Desa Kaliabu communities became aware of the sites they could use to search for information. In fact, they already know the right keywords to find the information they need.

Although they claim to have difficulty when studying the operation of computers and the use of graphic design software because of their minimal educational background, it did not dampen their desire to learn and get a chance to get online job. In addition to searching for their own information they need through the internet and also improve their skills by attending training or courses. This is like that done by FH 29-year-old youth who previously had a job as a driver. He improved his skills in the field of graphic design by participating in private training. In addition, not only are ICT skills improving, the English proficiency of the community is increasing because of the communication used with the employers using English and also the information on the internet that they get sometimes using English. Since, English is not their mother language, the used of ICT can help them to improve their English.

\section{b. Impact on Motivation to Higher Education}

The increased ability and skill of the community towards ICT and English does not necessarily increase their motivation to continue their education. The convenience of those who are already able to earn money is the reason why they are reluctant to continue their formal education. This is as expressed as follows: "The problem they've already got into work, already have the money, so they think school is not important anymore. Since, all they think is the reason to get education is to find job, so after get job they think school is unnecessary." (FH, March 7th 2017) 
Even so, there are young people who are able to continue formal education due to its participation as a logo designer. This is experienced by 21-year-old youth, $\mathrm{RN}$. He plunged as a logo designer when he just graduated high school. After graduation, he continued his education by taking informatics major at a college in Magelang. The cost of this education he got from the result became a logo designer. Even RN confessed, he has a desire to continue his education to master's degree.

\section{c. Impact on School}

Opportunities to utilize ICT is able to make people get online job is spread to all levels of society in Desa Kaliabu. This also gives an unpleasant impact on education. Introduction to the use of ICT by becoming a logo designer who knows no age limit, making the children at elementary school level (SD) already know the opportunity to earn income from this job. This also makes them become less concentrate at school because at night they will practice or work as logo designer. Parents also tend not to prohibit and support the involvement of their child because parents who are more benefited if their children get results. According to a teacher in Desa Kaliabu, the involvement of elementary school children into this logo designer profession will disturb the child's soul because they already know the function of money and make them lazy to go to school. As expressed with annoyed tone as follows: "... because it's influence began to the soul of the child ... Yeah, most of them should not involved but in fact in here student already started to take that opportunities. They only see economic benefit from it. They become lazy to go to school... "(GMD, March 9th 2017)

In addition to affecting children who are still in school, the logo designer profession also affected children who have graduated from elementary school so they have a reluctance to continue their education to a higher level. The large number of children's involvement is influenced by the economic condition of the parents. Despite that, with the increasing knowledge society possesses after being involved as a logo designer, the mindset of society becomes changed. They become more mature. Community maturity has also changed the way people speak and the language they use. In addition, they are now more thinking about the future and the curiosity increases. Though the idea of a growing future in society is more to invest in economic terms.

Looking at the things already described above then the utilization of ICT in Desa Kaliabu has increased human capital. Human capital is the abilities and skills that workers possess that affect their productivity (Green, 2012). The components of human capital are the competencies that people use in work such as knowledge, skills, competencies and also experiences (Kungwansupaphan \& Siengthai, 2014). Andrade \& Urquhart (2009) say human capital represents an indispensable individual ability to benefit from existing new technologies from an individualistic perspective. In this individual perspective is the individual's ability to identify, incorporate, and utilize 
new information, based on prior knowledge. Meanwhile, Adi (2013) links human capital with matters relating to qualified human resources that can master technologies that benefit the community, be it simple technology and advanced technology. Without the human element that has sufficient capability, engine or existing technology, becomes useless. To control the existing technology, education plays an important role in preparing the human capital that exists within a community.

Human capital that existed before the utilization of ICT in Desa Kaliabu is the lack of educational background. Although minimal educational background is indeed a human capital that tends to be less good because strong human resources should have an educational background that occupies to get a decent job. However, in the utilization of ICT in Desa Kaliabu, the lack of educational background into an asset that allows people to accept the presence of the logo designer profession. Desa Kaliabu community also has the competence to be able to plunge into a logo designer profession. The competences that they have are the soul of creativity, competition mental and have the motivation to change their life to better.

The existence of ICT utilization through the logo designer profession has increased the human capital of the community by improving their skills in computer operation, developing skills in using graphic design software, and also expertise in searching information through internet. This also further supports them in doing their work as a logo designer. Not only that, the ability in the use of English became increasing. Although it has gained new skills, people who are generally young do not have the motivation to continue education to a higher level. They already feel quite with the skills they get through the utilization of ICT because it has brought them to get a job. So, this becomes a dilemma of the utilization of ICT conducted in Desa Kaliabu. Not only that, the opportunities that are also used by children who are still in school to make them disturbed in the learning process and neglect his formal school. Nevertheless, RN became a young man who proved that after using ICT and getting a job because of his ICT utilization, his motivation for continuing his education did not diminish. RN should be able to be a role model for school-aged children who are already involved in ICT utilization but ignore their formal schooling.

Therefore, despite the adverse impacts, the utilization of ICT in Kaliabu Village through the existence of the logo designer profession has increased human capital in the community. People who initially only have the ability to do work as farmers or factory workers are now able to do the job as a logo designer.

\section{DISCUSSION}

Youth in Desa Kaliabu are able to empowerthemselves by successfully creating new jobs. Jobs that were not previously thought by them who only worked as drivers, labours, or farmers. The less prominent village potential and fewer employment opportunities in the villages encourage them to seek new employment alternatives through the utilization of ICT (Azzasyofia, 2017a). Desa Kaliabu is not the 
first village to be introduced with the utilization of ICTs, but the youth in this village have benefited the most. This village can be regarded as a pioneer village whose people are able to create jobs as a $\log o$ designer by the utilization of ICT.

In fact, Desa Kaliabu is not the first village in Kecamatan Salaman to be introduced to the logo design profession. The neighboor village, Desa Krasak is the first to know the existence of this designer logo profession. However, in this village the profession does not become spread because it is only done by some people. While in Desa Kaliabu, logo designer profession began to be known preceded by $A Q$, internet cafe worker, who knows the information and opportunities of this profession through his friends from Magelang city. Then AQ introducing it to other youth in his village. As experienced by $\mathrm{AB}$, who said if his involvement as a logo designer stems from his frequent visits to the internet cafe, then introduced by AQ with the profession. As expressed as follows: "I do not know, I never think about become logo designer. I am a driver. And one day, I came to the internet cafe, $A Q$ introduced me. He told me "learn this course". "(AB, 05-122016)

After $\mathrm{AB}$, finally many other young people known about the profession. Apart from the internet cafe, the introduction of this profession is also done by friends or family. This is as done by $\mathrm{FH}$, as the first youth in his hometown FH share his knowledge of the logo design profession to his cousins and also his bestfriend. The widespread introduction of the existence of this profession in Desa Kaliabu due to the learning process that uses they mother language, javanese. AQ as the person who first introduced this profession in Desa Kaliabu, teaches using a language that is easily understood by his friend so that his friends who do have a minimal background like $\mathrm{AB}$ who only graduated high school and do not have a graphic design background will be easy to understand. This method of teaching applied to AQ was also applied by $\mathrm{AB}$ and other youths while teaching other young people interested in trying this profession.

The introduction process of the logo designer profession in Desa Kaliabu in 2010 did not last long until it was recognized by all villagers. Its existence led to the formation of community that accommodates these youths, called Rewo-rewo community established in 2012. Over time this community no longer exists because not only young men who joined this profession, women also start to know and learned this profession. In fact, many school-aged children also know and participate in this logo designer profession. The introduction process that started from the internet cafe, then between close friends and family made the population quickly know this profession. The utilization of ICT through logo designer profession conducted by Desa Kaliabu community is a form of empowerment of village community that begins because of society that is not happy with their condition in this case do not have decent job then they introduced with logo designer profession and succeeded in making changes to them specially made them able to improve their economy (Azzasyofia, 2017b).

$\mathrm{AQ}$ role in the deployment of the logo designer profession in his village is enormous. AQ is an enabler that make empowerment in Desa Kaliabu succesed. 
Braun (2017) says that agency as a person actively initiates an action directed towards achieving a specific goal. Referring to this understanding, it can be said AQ as an agent of change on the empowerment of youth in Desa Kaliabu. AQ plays the role of informers and trainers to their friends about the logo designer profession. Not only AQ, $\mathrm{AB}$ and $\mathrm{FH}$ are also change agents in Desa Kaliabu where they take on the role of widespread information they get from AQ on the logo designer profession and invite other friends to make changes together with learning as a logo designer.
In addition to introducing of the logo designer profession, $\mathrm{AB}$ also became the initiator of the establishment of youth community in Desa Kaliabu called rewo- rewo. This community stands because of the conflict between the designers because of plagiarism. Although the survival of this community was later hampered by differences of interest, but the emergence of this community also makes the more familiar the profession of logo designer in Desa Kaliabu. When active, rewo-rewo community routinely meet with experts to improve their skills in becoming logo designers. Thus, the rewo-rewo community is

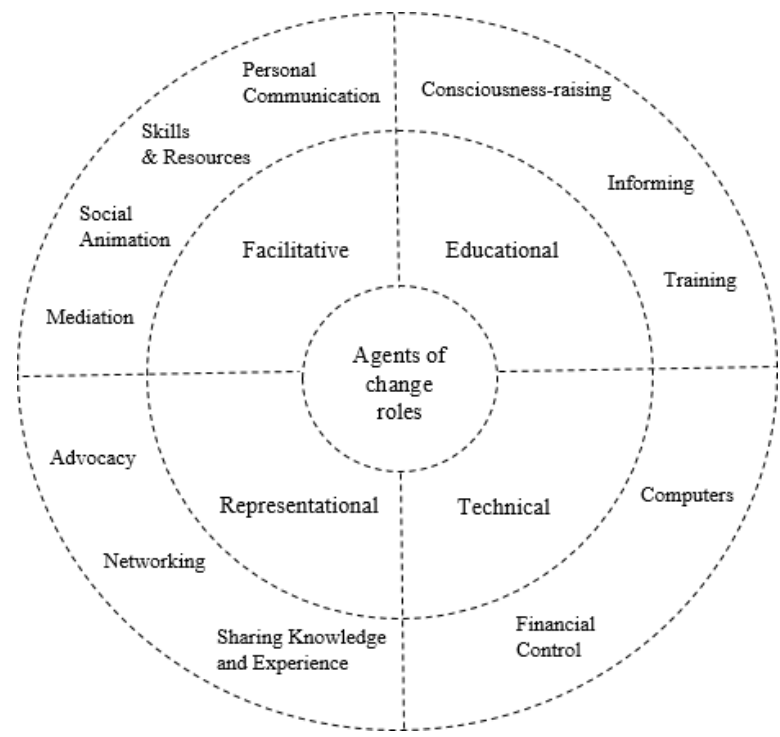

Figure 3 The role of change agents in community empowerment using ICT at Desa Kaliabu Source: Adapted from Ife (2013)

also an agent of change that makes the success of youth empowerment in Desa Kaliabu. Based on that, the change agents in Desa Kaliabu has the roles and skills of community workers expressed by Ife (2013) as they have educational, technical, representational, and facilitative roles and skills like community workers (Fig. 2).

In the first role, facilitative roles, the change agents of Desa Kaliabu, especially $\mathrm{AQ}$ and $\mathrm{AB}$ has good personal communication skills, so they are easy to spread the existence of logo designer profession to the public. In addition, AQ's profession as a worker of the internet cafe makes him often communicate with his customers making it easy for him to approach and teach the youth in Desa Kaliabu about the logo designer profession. The change agents of Desa Kaliabu has the role of maintaining the skills and resources because AQ has graphic design skills so that he can teach well his friends to worked as a logo 
designer. While in the case of social animation role because $\mathrm{AQ}$ and $\mathrm{AB}$ can be an inspiration for other communities to participate in changing lives by becoming a logo designer. In terms of the role of mediation, it is seen from the $\mathrm{AB}$ who became the initiator of the role of mediation, it is seen from the $\mathrm{AB}$ who became the initiator of the establishment of rewo-rewo community because initially he was asked to mediate from the conflicts that occur between youth who already become logo designer in his village.

In educational roles, change agents, in this case AQ and AB have a consciousnessraising role because they begin the introduction of the logo designer profession to raise awareness of Desa Kaliabu community that they can get decent job. To unleash this public awarenessed they play the role of informing and training where they provide information about the profession of logo design and proficiency that will be obtained through this profession. They also provide teaching to the community so that they are able to get results from the logo designer profession. Representational roles, visible from the $\mathrm{AB}$ who became representative of Desa Kaliabu logo designers to convey the aspirations of them to the government as well as to the private parties who come to Desa Kaliabu to provide assistance to the empowerment they done. In terms of networking, AQ who has friends who have graphic design knowledge make it introduced to the logo designer profession. In the process of introduction and learning to be a logo designer, both $\mathrm{AQ}$ and $\mathrm{AB}$ share knowledge and experience that they have to their friends. While in technical roles, of course the ability to use and operate a computer owned by AQ become one of the advantage so that the logo designer profession can be known by the Desa Kaliabu community. While the role of financial control is owned by $\mathrm{FH}$ who is trusted to help his friends in disbursing money from the results of their While the role of financial control is owned by $\mathrm{FH}$ who is trusted to help his friends in disbursing money from the results of their logo designer profession. Not only have the role required by the Desa Village community, the Desa Kaliabu change agents who are a part of Desa Kaliabu community also become an advantage of the succeded of empowerment using ICT in this village.

\section{CONCLUSION}

Utilization of ICT conducted in Desa Kaliabu through logo designer profession has increased human capital of society. Human capital perceived to be increasing by the community is by increasing their expertise in using ICT so as to be able to empower the community of Desa Kaliabu. The empowerment by the utilization of ICT in Desa Kaliabu has led to the logo designer profession that is able to bring change in Desa Kaliabu especially in improving their economy. The existence of change agents plays an important role in the success of village empowerment, especially the empowerment of youth of Desa Kaliabu by providing them alternative employment. The change agents are a Desa Kaliabu community who wants to make changes in their village. Thus, it is easy for these change agents to dothe empowerment in their village because they understand the need and right method to empower their 
community. With the utilization of ICTs, the society are able to participate in development. Therefore, increased skill on ICT and the introduction of benefits that can be obtained through the utilization of ICT will be able to empower people, especially people who live in rural areas. Social worker as agent of change can use this method to empower people in the community can make them more involve to development in general.

\section{REFERENCES}

Adams, R. (1990). Self-Help, Social Work and Empowerment. Hampshire: Macmillan Education LTD.

Adi, Isbandi R. (2013). Intervensi komunitas \& pengembangan masyarakat: sebagai upaya pemberdayaan masyarakat. Jakarta: Rajawali Pers.

Ahmed, A., \& Al-Roubaie, A. (2013). Poverty reduction in the Arab world: the use of ICTs. World Journal of Science, Technology, and Sustainable Development, 10(3), 195 - 211.

Andrade, A. E., \& Urquhart, C. (2009). The Value of Extended Networks: Social Capital in an ICT Intervention in Rural Peru. Information Technology for Development, 15(2), 108-132.

Azzasyofia, Mira, Adi, Isbandi R. (2017a). Job Opportunities Through Information and Communication Technology in Rural Area: Case Study Desa Kaliabu, Central Java. Man in India, 97(24-II), 149-158.

Azzasyofia, Mira, Adi, Isbandi R. (2017b). Pembangunan Sosial Pedesaan Melalui Pemanfaatan Teknolohi Infformasi dan Komunikasi (TIK). Jurnal Ilmu Kesejahteraan Sosial, 18(2), 139-149.

Badan Pusat Statistik (BPS). (2017). Laporan Bulanan Data Sosial Ekonomi. Jakarta: BPS.

Braun, J. v. (2017). Children as Agents of Change for Sustainable Development. In P. L. Antonio, et.all, Children and
Sustainable Development: ecological education in a globalized world (pp. 1730). Gewerbestrasse: Springer.

Braye, S., \& Preston-Shoot, M. (1995). Empowering practice in social care. Maidenhead: Open University Press.

Castells, M. (1999). Information Technology, Globalization and Social Development. UNRISD Discussion Paper, 114.

Green, G. P., \& Haines, A. (2012). Asset building and community development (3rd ed.). Los Angeles: SAGE.

Ife, J. (2013). Community Development in an Uncertain World. Port Melbourne: Cambridge University Press.

Kivunikea, F. N., Ekenberga, L., Danielsona, M., \& Tusubira, F. (2011). Perceptions of the role of ICT on quality of life in rural communities in Uganda. Information Technology for Development, 17(1), 61-80

Kungwansupaphan, C., \& Siengthai, S. (2014). Exploring entrepreneurs' human capital components and effects on learning orientation in early internationalizing firms. Int Entrep Manag $J, 10,561-587$.

Narayan, Deepa, (ed.). (2002). Empowerment and Poverty Reduction: A Source Book. Washington D.C: The World Bank.

Neuman, W. L. (2014). Social research methods: qualitative and quantitative approaches (7th ed.). Harlow: Pearson.

Ng, Wan. (2015). New Digital Technology in Education: Conceptualizing Professional Learning for Educators. Cham: Springer International.

Organisation for Economic Cooperation and Development (OECD). (2005). New perspectives on ict skills and employment. Paris: OECD.

Puskakom UI, (ed.). (2015). Profil Pengguna Internet Indonesia 2014. Jakarta: APJII.

Shardlow, S. (1998). Values, ethics and social work. In R. Adams, L. Dominelli, \& M. Payne, Social Work: themes, issues, and critical debates (pp. 23-33). London: Macmillan Press Ltd. 